\title{
Cow Milk Protein Antigen IgE Antibody Measurement
}

National Cancer Institute

\section{Source}

National Cancer Institute. Cow Milk Protein Antigen IgE Antibody Measurement. NCI

Thesaurus. Code C147280.

The determination of the amount of cow milk protein antigen IgE antibody present in a sample. 